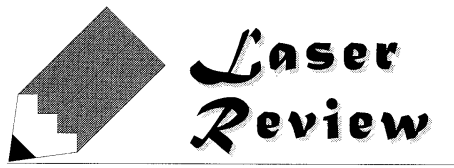

\title{
フォトニック結晶ファイバの製作技術
}

\author{
遠山修，伊藤 秀明，山口 俊一郎 \\ 三菱電線工業(株)（广660-0856兵庫県尼崎市東向島西之町8）
}

\section{Manufacturing Technology for Photonic Crystal Fibers}

\author{
Osamu TOHYAMA, Hideaki ITOH, and Syun-ichiro YAMAGUCHI \\ Mitsubishi Cable Industries, Ltd., 8, Nishino-cho, Higashimukoujima, Amagasaki, Hyogo 660-0856
}

(Received August 1, 2005)

\begin{abstract}
Dramatic advances in research and development on photonic crystal fibers have created new properties that have not been achievable using conventional fibers. Photonic crystal fibers have many fascinating features. The very high relative refractive index between the fiber core and air hole cladding enables several prominent properties, notably endlessly single-mode operation, high nonlinearity, wide-ranging dispersion management, and the ability to maintain high polarization. The processes involved in manufacturing photonic crystal fibers are quite different from those used to manufacture conventional fibers, largely due to the profusion of air holes in the silica glass that comprises photonic crystal fibers. Our research group has optimized the technology to manufacture photonic crystals with the required optical characteristics. This paper describes the manufacturing technology we have developed to produce photonic crystal fibers with low attenuation and high reliability.
\end{abstract}

Key Words: Photonic crystal fiber, Preform, Stack and draw method, Low attenuation, High reliability

\section{1.はじめに}

フォトニック結晶ファイバ(Photonic Crystal Fiber: PCF) はファイバ断面内に屈折率が周期的に変化する構造を持 つファイバである。そのほとんどが屈折率が約 1.45 の純粋 石英に屈折率1の空気を含むエアホールがファイバ断面内 に周期的に配列し, そのエアホールはファイバ軸方向に 沿って伸びている，フォトニック結晶ファイバは，その コアと空孔を含むクラッドにより得られる非常に大きい 比屈折率差により, 超広帯域シングルモード動作 ${ }^{1)}$, 高非 線形 2 ，分散制御 3 ），偏波保持4)，低曲げ損失性5)等の独特 の特性を得ることができる。一方，多数の微細なエア ホールを有する断面構造を実現するためには, 従来の光 ファイバとは全く違った新規の製作技術の開発が必要と なる、特に前記特性を実現するために設計されたエア ホール径とエアホール間のピッチを再現性よく製作する ためには，特殊な母材の構成の実現や線引方法を開発す る必要がある。

本稿では, 各種構造・用途に適したフォトニック結晶 ファイバの母材作製及び線引技術を述べるとともに，実 用化に向けての重要課題である損失低減のための対策及 び信頼性確保に関して，いくつかの試験結果をあわせて 報告する。

\section{2. 構 造}

フォトニック結晶ファイバの断面構造図を, Fig. 1に示 す. Fig. 1 (a)は，コアと空孔を有するクラッド部分との 屈折率差により光を閉じ込めて伝搬させる屈折率導波型 であり，多くの独特な特性が実現可能な一般的な夕イプ である.Fig. 1（b)は，屈折率導波型の一種で，大きな工 アホール径で少数のエアホールからなるエアクラッド型 である。これは，Fig. 1（a）を簡略化させたもので，極限 られた特性が必要な場合に用いられる。 Fig. 1 (c) は, 通

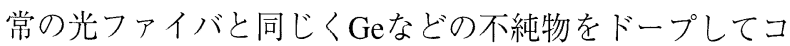

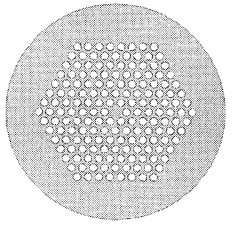

(a) Index guiding PCF

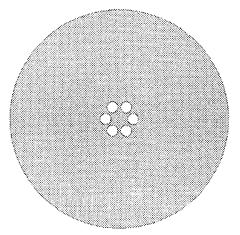

(b) Air-clad fiber

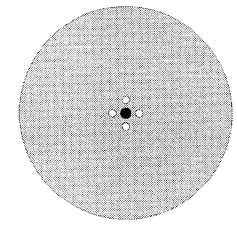

(c) Hole-assisted fiber

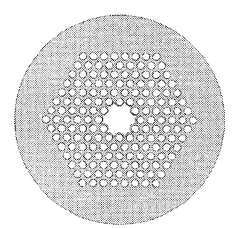

(d) Photonic bandgap fiber
Fig. 1 Structure of photonic crystal fibers. 
アで実現したうえで，コアの周りにホールをいくつか設 けたホールアシスト型であり，特に曲げ損失特性改善の 目的で用いられることが多い.Fig. 1 (d) は，中空コアを 有するフォトニックバンドギャップ型で，光は中空部分を 伝搬するので，従来の石英ファイバでは伝搬できなかった 短波長 (紫外)伝送やハイパワー伝送が期待されている.

\section{3. 製造方法}

\subsection{Stack and Draw法 (Capillary法)}

Stack and Draw法とは，クラッド領域のエアホールを構 成するキャピラリ (石英細管)を所望のサイズに線引きし, これを多数積み重ね (Stack) てサポート管に挿入し，さら に中心にあるキャピラリをコア材料(例えば純粋石英)に置 換してプリフォームとし，これを線引(Draw)する方法で ある。また中空のパイプでエアホールクラッドの出発材 を組み立てることから，キャピラリ法とも呼ばれてい る。作製プロセスをFig. 2に示す．出発材料のサイズに自 由度が大きく，ホール数の多いPCFも比較的容易に作製で きるため，汎用性のある方法である。例えば，コア直 径，キャピラリの外径・肉厚及びサポート管の外径・肉 厚を変化させるだけで，各種特性を有するフォトニック 結晶ファイバを作製することが可能である．Fig. 1 (a), (c) は本方法で作製されることが多い. 但し，エアホール 数が非常に多い夕イプのフォトニック結晶ファイバを作 製する場合，サポート管の内径・形状，キャピラリの外 径の寸法公差を厳密に管理しないと，コアの偏心が発生 する可能性がある。

\section{2 ドリル法}

ドリル法とは，円筒純粋石英ガラスロッド，もしくは 中心部分に $\mathrm{Ge}$ 等の不純物添加によるコア領域を有する ロッドに，ドリルでエアホールに相当する穴を空けてプ リフォームとし，これを線引する方法である。プリ フォームの形状をFig. 3に示す.この方法はStack and Draw 法のような偏心の可能性はほとんどないが，石英ガラス という脆性材料に精度良く多数のエアホールをドリルで 穿孔することが難しいため，比較的エアホール数の少な いフォトニック結晶ファイバ(例えばFig. 1 (b), (c))の作 製に適している。また同様の理由で母材の大型化も難し いため，長尺線引きによるコストダウンが期待できない

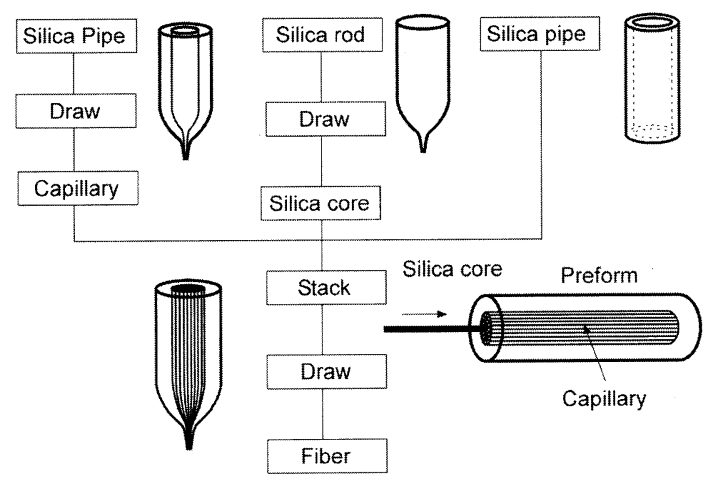

Fig. 2 Stack and draw method.

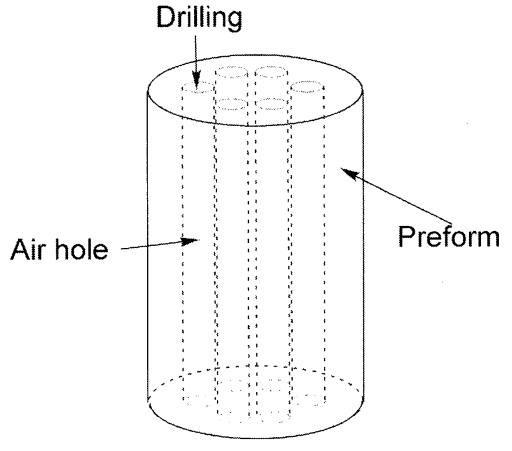

Fig. 3 Drilling method.

方法である。

\section{3 線 引}

前記方法にて得られた母材は，従来と同様の線引機に より外径 $125 \mu \mathrm{m}$ 程度のファイバに加工される. Stack and Draw 法により得られた母材の線引きには，溶融一体線引 法6)が用いられる。これはイメージガイドファイバ7)の線 引きのために開発された方法で，サポート管に詰め込ま れた数千から数万本の画素ファイバ間の隙間を減圧状態 にしながら溶融一体化するものである，但しフォトニッ ク結晶ファイバの場合は詰め込まれているのがキャピラ リであり，キャピラリ間の隙間を減圧状態にした場合， 得られたファイバのエアホールの形状が変形してしま う。そこでキャピラリ間の隙間を減圧しつつ，キャピラ リ内を加圧するという方法が必要である。このため母材 に圧力コントローラを装着して，キャピラリ間，キャピ ラリ内の圧力を精密に制御しながら線引きする方法を とっている。ドリル法によって得られた母材も，同様の 方法でエアホール内の圧力が制御されている。線引装置 の概略図をFig. 4に示す.

\section{4. 構造設計}

\section{1 偏波保持型}

フォトニック結晶ファイバは，エアホールの直径 $(d)$, エアホール間隔 $(\Lambda)$ を適宜選択することにより, 各種特性 を得ることができる。例えば，偏波保持特性を得るため には，ファイバ断面の直交軸のNA(Numerical Aperture: 開 口数)に異方性を与えれば良いので，Fig. 5に示すようにコ アロッド最近傍のキャピラリ2本の内径を大きくするだけ でよい，応力付与ロッド2本をコアの両側に象嵌する従来 法に比べ，非常に簡便に母材を作製することが出来る. このようにして作製された偏波保持型フォトニック結晶 ファイバの断面写真をFig. 6に示す.

\section{2 分散制御}

フォトニック結晶ファイバの分散もエアホールの直径 $(d)$ ，エアホール間隔 $(\Lambda)$ によ，容易に設計することが

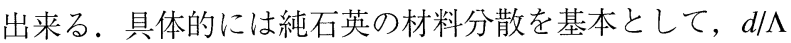
を調整し，構造分散を重畳させることにより様々な分散 特性が得られる。エアホール径とエアホール間隔を変化 


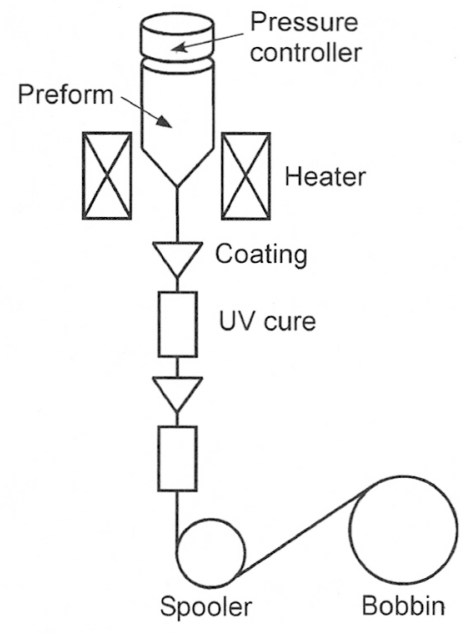

Fig. 4 Drawing of preform.

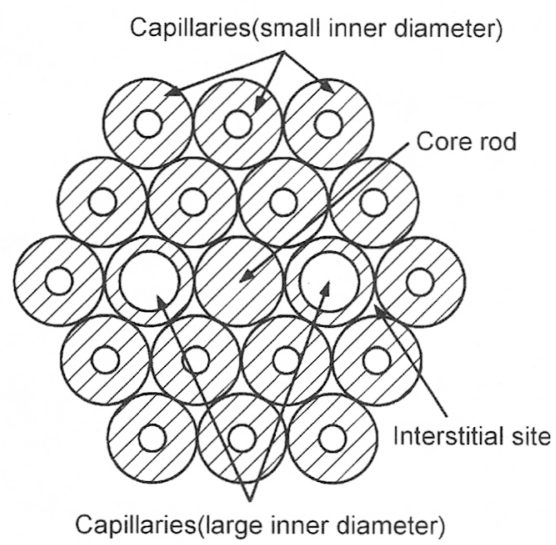

Fig. 5 Array of capillaries and rod for polarization maintaining.

させたときのフォトニック結晶ファイバの分散をFig. 7に 示す。エアホール径やエアホール間隔が小さくなるにつ れて，零分散波長が短波長側にシフトしていることが分 かる．さらにコア領域への不純物添加によっても分散の 調整が可能であり，これらのパラメー夕を適当に設定す ることにより短波長零分散，通信带での高異常分散，任 意の波長での分散フラット等の分散特性が実現される。

\section{5. 低損失化}

通常の光ファイバの損失要因は, ガラス中の不純物吸 収(特にOH吸収), 構造不整抢よびレイリ一散乱である。 フォトニック結晶ファイバも同様の損失要因に支配され る。したがって, 全損失を要因別に分解して表すと, 通 常の光ファイバと同様に,

$$
\alpha(\lambda)=A \lambda^{-4}+B+\alpha_{\mathrm{OH}}(\lambda)
$$

と表すことが出来る ${ }^{8}$.

レイリー散乱係数Aには石英ガラスの密度摇らぎの他, エアホール表面の微細な凹凸も影響していると推定され る。構造不整損失Bは，エアホールの寸法変動やエアホー ル表面の微細な凹凸が原因であると考元られる。OH吸収 損失はコア及びエアホール表面に残留している水分が原

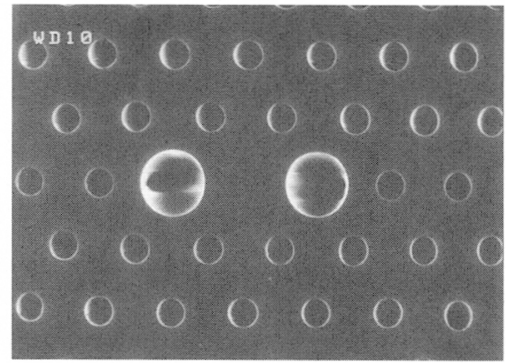

Fig. 6 Cross sectional view of polarization maintaining type photonic crystal fiber.

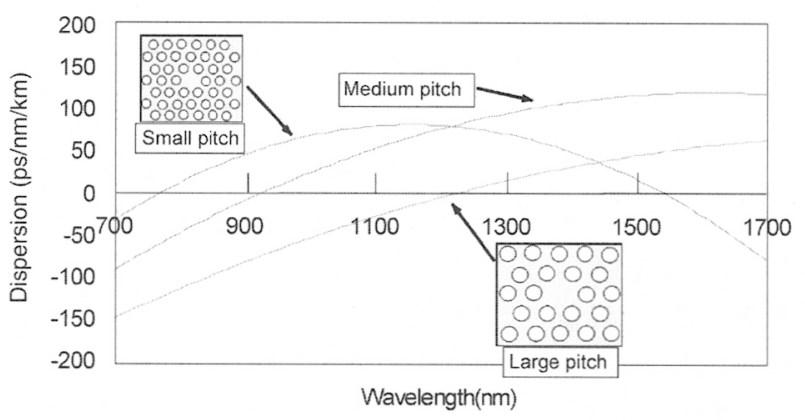

Fig. 7 Dispersion of photonic crystal fiber with various pitch.

因と考えられる，また，エアホール中に存在する水分子 の影響もあると考光られる。いずれにしろ，エアホール 表面の影響が大きく，この影響をいかにして小さくする かがフォトニック結晶ファイバの低損失化の課題であ る。波長と損失の関係を，横軸を $1 / \lambda^{4}$ としてプロットした ものをFig. 8に示す.

具体的な低損失化の方策として，キャピラリをスタッ クして作製した母材の脱水処理，線引温度・速度の最適 化によるキャピラリ内面の平滑化，断面空孔配置の高精 度化等を検討した。母材作製工程中に脱水処理を施した フォトニック結晶ファイバの損失特性の一例をFig. 9に示 す。このフォトニック結晶ファイバの構造パラメータは $\Lambda$ $=7.3 \mu \mathrm{m}, d=4.2 \mu \mathrm{m}$ であるが, 損失は， $0.35 \mathrm{~dB} / \mathrm{km} @ 1.55$ $\mu \mathrm{m} と 0.5 \mathrm{~dB} / \mathrm{km}$ 以下を達成している。また，レイリー散乱 倸数 $A=1.02 \mathrm{~dB} / \mathrm{km} \cdot \mu \mathrm{m}^{4}$, 構造不整損失 $B=0.25 \mathrm{~dB} / \mathrm{km}$ と, 通常の光ファイバの值にかなり近づいていることがわか る.

\section{6. 信頼性の確保}

フォトニック結晶ファイバは，その端面を解放状態に した場合，水分を含九だ空気がエアホール内に滲入し， ファイバ端面が污染されたり，伝送損失に温度依存性が あることは既に報告されている99. そここで実用上，フォト ニック結晶ファイバには真空乾燥処理を行ない, 乾燥ガ スによりエアホール内を置換した上で，両端を何らかの 手段により封止し，外部とエアホールとの相互作用を遮 断する必要がある ${ }^{10)}$ 。信頼性確保のための封止方法の検 討結果を以下に述べる。 


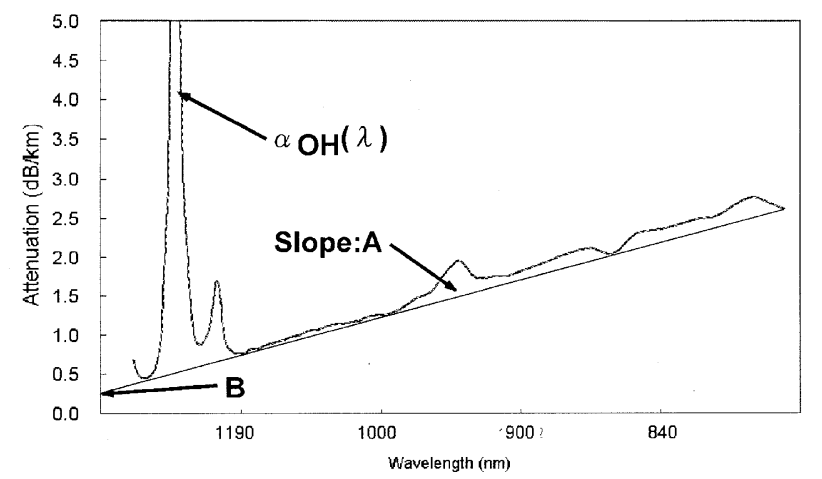

Fig. $81 / \lambda^{4}$ plot.

\section{1 ファイバ接続}

フォトニック結晶ファイバを実際に応用する場合，ピ グテールファイバを接続することが好ましい。これによ り他のデバイス (例えば光源, 検出器等) との接続が容易と なる。このピグテールファイバ接続には，フォトニック 結晶ファイバの端面封止の役割も担わせることができ る。そこでフォトニック結晶ファイバと通常のファイバ との接続を検討した。

先ず，接続時の損失を低減するためには，フォトニッ ク結晶ファイバとほぼ同一のモードフィールド径 (Mode Field Diameter: MFD)の光ファイバを接続する必要があ る。そこで，最も接続が難しいと考えられるコア径の小 さい高非線形フォトニック結晶ファイバとモードフィー ルド径の小さい分散補償ファイバ(Dispersion Compensating Fiber: DCF，今回使用したのはコア径： $2.01 \mu \mathrm{m}, \Delta: 1.89$ $\%$ ，モードフィールド径： $4.7 \mu \mathrm{m} @ 1.55 \mu \mathrm{m})$ との融着接続 を検討した。

フォトニック結晶ファイバと通常のファイバとを融着 接続する場合の模式図をFig. 10に示す。融着接続機のアー ク放電によりファイバの先端が溶融し，フォトニック結 晶ファイバのエアホールが潰れて，Fig. 10のように接続さ れていると考えられる。この場合，コアが純粋石英であ るため，溶融した部分は導波構造を持たない単なる石英 棒となってしまう。このためフォトニック結晶ファイバ 中を導波してきた光は，融着接続部で大量に漏れてしま い接続損失が非常に大きいものになってしまう。そこで この溶融領域の長さ (溶融長) を極限まで短くして融着する 必要がある。よってアーク放電強度，時間，融着時の押 し込み応力等のパラメータを最適化して，融着接続の低 損失化を図った。融着接続には放電強度，放電時間等の

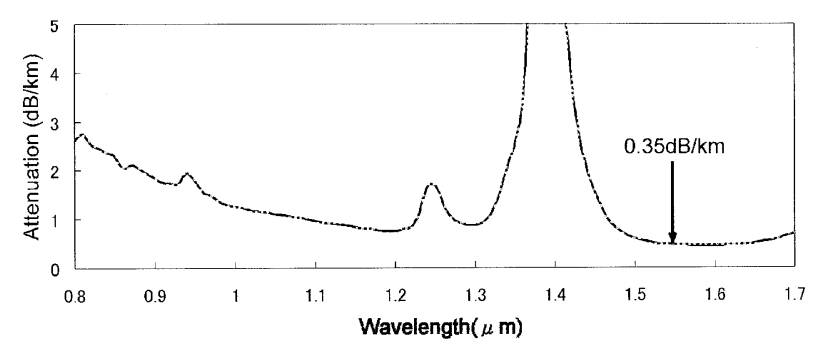

Fig. 9 Loss spectrum.
接続条件及び調芯等が設定可能な，市販の融着接続機を 使用した。実際の接続は入射光の透過パワーをパワー メータでモニ夕しながら，損失が最低になるように放電 時間等の接続条件を調整して行った。

フォトニック結晶ファイバのコア径に対する接続損失 をTable 1に示す．表から明らかなように，フォトニック結 晶ファイバのコア径と接続したDCFのモードフィールド径 の不一致により，接続損失が大きくなっている。また融 着によりフォトニック結晶ファイバのエアホール構造が 潰れることも，接続損失の増加の原因と考えられる。

よって出来る限りモードフィールド径が近いファイバ もしくは，どうしてもモードフィールド径の差が大きい ものについては, 中間のモードフィールド径をもつバッ ファファイバを挿入して融着接続する必要がある。このよ うにして融着接続した結果をFig. 11に示す。モードフィー ルド径を合わせることにより，フォトニック結晶ファイ バと通常のシングルモードファイバを約 $0.3 \mathrm{~dB}$ の低損失で 接続することが可能である.

\section{2 コネクタ装着}

実際のフォトニック結晶ファイバの応用を考えると， さらにコネクタ装着が必須である。但しフォトニック結 晶ファイバの場合は端面に多数の空孔が存在するため, 従来のようにフェルールをつけて研磨すると，空孔から 研磨時の水・研磨粉を吸い上げる，研磨粉により空孔が

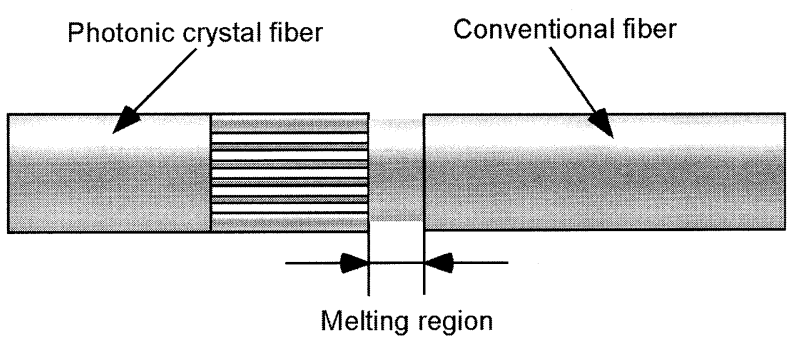

Fig. 10 Schematic diagram of connecting point.

Table 1 Connection loss between PCF and DCF.

\begin{tabular}{cc}
\hline $\begin{array}{c}\text { Core diameter of PCF } \\
(\mu \mathrm{m})\end{array}$ & $\begin{array}{c}\text { Connection loss between } \\
\text { PCF and DCF } \\
(\mathrm{dB})\end{array}$ \\
\hline 1.7 & 6.57 \\
2.0 & 3.99 \\
2.6 & 2.32 \\
\hline
\end{tabular}

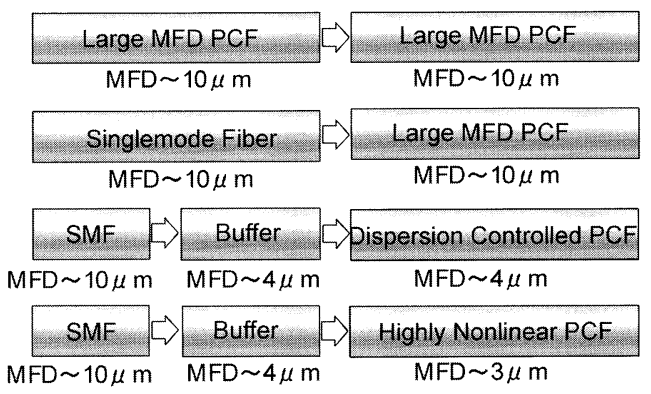

Loss $_{1550 \mathrm{~min}}$

$0.4 \mathrm{~dB}$

$0.3 \mathrm{~dB}$

$0.9 \mathrm{~dB}$

2.7dB 
崩れる等の問題があり，そのまま研磨をしてコネクタを 装着することが出来ない。これらの影響を無くして端面 を研磨してコネク夕装着するには，フォトニック結晶 ファイバ端面を何らかの方法によって閉塞させる必要が ある。

閉塞材料には硬化時にファイバ(石英)と同一の硬度 (研 磨をしても封入部分が隆起・陷没しない)，エアホールと 同一の光学特性 (屈折率 $=1$ ) を持つものが必要となる. 特 に硬度については，接続時に回転方向に力が発生するFC コネクタについては, 特に重要である. 現在市販の樹脂 で前記特性を満足するものは無く, 独自に閉塞用の樹脂 を開発した。

次に問題となるのは閉塞充填長をどのように制御する かである. 先の融着接続と同様で, 充填領域は単なる石 英棒と同様の役割を果たす。よって充填領域を十分に短 く制御しないと, この部分から導波してきた光が漏れ, コネク夕接続時の損失が著しく大きくなる。このため, 樹脂の粘性を調整してある程度の充填長の制御が可能な 状態で閉塞し, 最終的には研磨によって精密に充填長を 定める方式で端面処理を実施した。ファイバ先端部の模 式図をFig. 12に示す.

この方法によってコネクタ装着をしたフォトニック結 晶ファイバ(短波長シングルモード型, MFD: $10 \mu \mathrm{m}$, 純粋 石英コア) と通常のシングルモードファイバをコネクタに より接続し，シングルモードファイバから通信用 LD (波 長： $1550 \mathrm{~nm}$ )の光を入射した場合のコネクタ接続損失を評 価した. 実験の構成をFig. 13に示す。この場合の接続損失 は約 $0.1 \mathrm{~dB}$ であり，シングルモードファイバ同士との接続 と遜色の無い結果が得られた。

\section{7. まとめ}

特殊な構造を持つフォトニック結晶ファイバに適し た，従来とは異なる新たな母材作製・線引方法について 述べた。現在では母材の大型化・線引技術の改善によ り，従来のシングルモードファイバと同様に，長尺での 線引きが可能となっている。また実用化に向けての重要 な課題である損失低減のための対策も検討し, 脱水処理 等の方法により低損失化が可能となった。ささらに信頼性 確保のためのファイバ端面封止についても，ファイバ . コネクタ接続を検討し, 空気・水・コンタミネーション 等の浸入による特性の劣化を抑えることができた。

フォトニック結晶ファイバは既に広範な波長域(紫外,

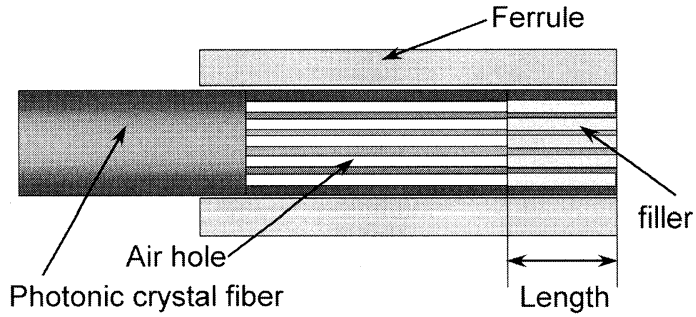

Fig. 12 Schematic diagram of a tip of PCF.

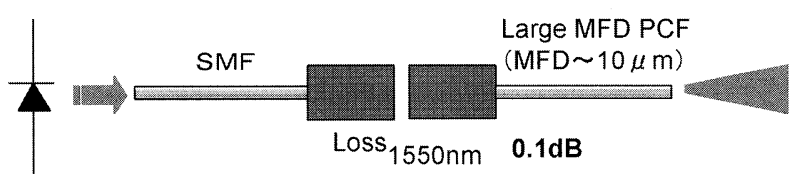

Fig. 13 Connection loss.

可視，赤外)で実用が開始されており, さらなる品質の向 上が今後の課題である。

\section{謝 辞}

日頃ご指導頂いておりますNTT未来ねつと研究所の萩 本所長, 山林部長, 並びに川西リーダはじめ同所の研究 員の皆様に感謝いたします. 本研究の一部は, 文部科学 省科学技術振興調整費による開発課題「ブロードバンド光 シンセサイザの開発」において得られたものです.

\section{参考文献}

1) T. A. Birks, J. C. Knight, and P. St. J. Russell: Opt. Lett. 22 (1997) 961.

2) 木下 貴陽, 田中正俊, 伊藤 秀明, 遠山 修, 藤田 盛行: 電 子情報通信学会総合大会 (2005) CS-12-10.

3) T-L. Wu and C-H. Chao: IEEE Photon. Tech. Lett. 17 ( 2005) 67.

4) Y. Inoue, T. Aiba, and N. Shibata: IEEE Photon. Tech. Lett. 17 (2005) 1238.

5) K. Miyake, M. Hachiwaka, T. Kinoshita, S. Yamaguchi, H. Kubota, and S. Kawanishi: Proc. $30^{\text {th }}$ European Conference on Optical Communication (2004) Mo3. 3. 4.

6)内海厚：レーザー研究 12 (1984) 677.

7) 速水弘之, 大瀬 誓六, 蝉本 慶三, 石谷忠義, 内海厚: 大 日日本電線時報 No. 71 (1986) 74 .

8) 大越 孝敬, 岡本勝就, 保立和夫 : 光ファイバ (オーム社, 1983)p. 315

9) 田中正俊, 山取真也, 藤田盛行, 鈴木和宣, 久保田 寛和, 川西悟基: 電子情報通信学会ソサイエテイ大会 (2002) C-347.

10) O. Tohyama, M. Tanaka, T. Kinoshita, S. Yamaguchi, H. Kubota, and S. Kawanishi: Proc. $29^{\text {th }}$ European Conference on Optical Communication (2003) We2. 7. 2.

\section{スタック・アンド・ドロー法 (stack and draw method) \\ フォトニック結晶ファイバの線引方法のひとつで，ク} ラッド領域のエアホールを構成するキャピラリ(石英細管) を所望のサイズに線引きし，これを多数積み重ねてサ ポート管に挿入し，さらに中心にあるキャピラリをコア 材料(例えば純粋石英)に置換してプリフォームとし，これ を線引する方法である。この方法は特に新規なものでは なく，何万本もの画素ファイバを束ねてサポート管に挿
入し，これを溶融一括線引きするイメージガイドファイ バの製法として，従来から使用されている方法である. 但しフォトニック結晶ファイバの場合は, エアホール径 とエアホール間のピッチを正確に制御するため, キャピ ラリ間の空間を減圧し，キャピラリ内を加圧した状態で バランスを取りながら線引きするので，特殊な圧力制御 が必要となる。

(遠山修) 